\title{
Coal Consumption of Ships-of-War
}

\section{W. H. Riley Esq., R.N.}

To cite this article: W. H. Riley Esq., R.N. (1893) Coal Consumption of Ships-of-War, Royal United Services Institution. Journal, 37:188, 1069-1088, DOI: $10.1080 / 03071849309416937$

To link to this article: http://dx.doi.org/10.1080/03071849309416937

曲 Published online: 11 Sep 2009.

Submit your article to this journal

Џ Article views: 4

Q View related articles $₫$ 
Wednesday, June 7, 1693.

REAr-ADHiral EDJIOND J. CHURCH in the Chair.

\section{COAL CONSUALTION OH SHIPS.OF.TAR.}

By W. H. RuLEr, Esq., R.N., Staff Engincer.

THE subject of this paper is, no doubt, of special interest to a largo number of the members of the Royal United Service Iustitution and to naral officers generally, and also, judging from sereral published criticisms, would appcar to lare some attractiou outside the Roynl Nary. Under these circumstances it may not be out of place, and not withont some value, to offer some remarks for discussion in this Institution on actual expenditures of conl and circumstances counucted with its cconoms.

In the first place, a brief review will be made of the nature of tho services performed by a man-of-war for which coal is consurned, and its effect on the nceuracy of measuring those services and the amount of coal oxpended for their performance.

It is a matter of common knowledge that these scrvices are of a mach more varied and irregular character than those performed by merchant steamers. A large 1st class battle-ship, capablo of developing a maximum I.H.P. of about 13,000 and a speed of 18 knots, actualls on peace duty derclops I.U.P.'s which vary from 9,000 to less than 900, and speeds from $16 \frac{1}{2}$ knots to 6 knots. When a debinito passage is unade, it is often at a raricd specd, and, if steaming in company with other vessels, it is necessary for all but the leading ship to continually vary the revolutions in order to leep station, these rariations often taking place several times in an hour. Tho belnn also is brought into frequent requisition, affecting speed, rovolutions, and I.H.P. The continuity of a passage is also often further interrupted by evolutionary exercises, during which tho rariation of specd aud course is so great that it is impossible to measure the propelling performance.

Besides propulsion there are also several auxiliary services to be performed, comprising distillation from sea water for drinking and washing purposes, and for making good losses of boiler fecd; lighting the ship internally by celectricity; pumping water from sea for sanitary and cleaning purposes, from double bottoms, bilgcs, and drain receptacles; ventilating and stecring ship; compressing air for torpedo work; working guns by lyddraulio power; hoisting purposes 
and driving capstans, all of which, besides forming a raried series, are each in themselves of a more or less irregular character.

As regards propulsion, the variation described renders it extremely diffealt to accurately calculate the avernge power doveloped. When tho rerolutions are subject to such frequent alteration, the indicator dingrams will often be taken cither when the rovolutions are greater or less than tho aremge for the period the diagrams corer; and it is frequently the caso that in the interval betwecn taking tho diagrams from successire cylinders the rerolutions will be chnnged, thas giring not only unfair but inconsistent results. Tho principal sources of accurato data are the comparatirely rare occasions when the vessels happen to bo steaming independeutly over loug distances. It must bo borne in mind, howerer, that the results so obtained may differ considerably from the results obtained when making a passage under the raried conditions noted previously, although in tho two cases the average speed of passage may bo the same. When steaming irvegalarly a very rough approximation to the I.H.P. can bo obtained by calcalating the arcrago rerolutions per minute, and taking the I.H.P. corresponding to this as determined on tho measured mile trinls; this, however, is open to the objection that nothing is allowed for differences in the state of the weather and the ship's bottom, which circumstances aro found to haro a considerable effect, tho exact nmount of which is dificult to detcrmine. In nomo few cascs, the conditions as to weather and bottom may approximato to those under which tho measured mile trials wero made, when fairly reliable results as to arerago I.H.P. may be obtained in this way.

The amount of work done by the auxilinry engines and appliances is generally impossible to absolutely measare. Some of theso engines are fitted with means for taking indicator diagrams, and so enable the I.H.P. developed at a giren titno to be calculated; bat their work is generally of sach an intermittent and varied : character that this . wonld afford no measure of the arerage I.H.P. developed. A vers fair estimate of the serrices rendered by the electric lighting engines and the distillers can, howover, bo otherwise determined, the current generated by tho former being measurablo by elcetrical appliances, and the water made by the lntter by the capacity of the tanks into which the fresh water for drinking and washing parposes is delivercd. The other services are of such a chameter that they can only bo ralued by the amonit of coal they require to perform their usaal daily work.

$\Delta$ few remarks will now be made upon the degrec of accaracy with which the coal consumed can be measured and apportioned to the sereral services for which it is used. The ordinary method of mcasuring the conl taken out of tho bunkers is to fill backets of known capacity and to record or "tally" each as it passes from tho bankers into the stokeliold; one of these is occasionally weighed, both empty and when filled lerel with the top with conl, tho difference giring the weight of coal per bucket. Of courso this system of measuring in detail is open to several sources of crror, such as when tho buckets are nut all filled to the same height as those which hare 
becn weighed, or when erery bncket is not recorded; and also any inaccuracy in the weighing machine, or from clnmsiness in carrying out the operation, will bo multiplied when the reight so obtained is taken as the standard for several. It is customars, in somo ships, to allow a small percentage on tho cxpenditure so obtained; to aroid a greater quantity being used than is recorded; it is, howcrer, often found that. this percentage need only be rery minute when the staff has been well trained in coal tallying; and is made to understand tho importance of accuracy:

As a check on this method it is the common practice to measure the capacity of the coal in the bunkers; this being an especially accurnte method when sterming saflicieutly long to have completely cmptied onc or moro bunkers after baring been filled. Of course, for this to bo accumte, it is necessary that when the conl is taken on board, tho bunleers shonld be orenly trimmed up to the deck beams; this practice, having also the adrantage of taking on board tho greatest. quantity of coal, justifies the extrn timo taken during coaling to ensure it being done.

It has becn suggested that tho draught of water of tho ship affords an accurato means of measuring coal crpenditure; no doubt this would be so if caro and trouble wero taken to measure the quantity consumed of other stores, and if the ship were floating in absolutely smooth water when reading the draghht. The practice is frequently adopted at Government coaliug depôts, the coaling lighters used there being filled in places whero the water is generally smooth and the calcalations not confused by tho weight of any other stores. The uncthod is hardly necessary in ships, as tho two first alluded to should be sufficient to ensuro a fair degrce of accuracy.

It is an important point to apportion the amount of coal used to the several serrices, and in somo enses it requires a considerable amount of paticnce and tronblo to attain this end. The adrantago obtaincd, howerer, is worth the trouble, as in cases of high expen. diture it enables the cause to bo better traced.

Several ships, including all the more recent, have cither an auxiliary boiler or ono or more of the main boilers specially fitted for the purpose, which can be connected up only to the usual main lend of ansiliary steam pipe which supplics stcam to all the auxiliary machiners. Thus the main and anxiliary machinery, although working concurrently; can be worked independently, and the copl expended for each realily determined. The amount required for each axailiary scrvice presents greater complications, but can bo approximately obtaincd by haring only ono at a time in operation for a sufficient period to enable tho coal used to bo properly measured. These individual results added together will gire a greater total than is obtained when all the nuxiliary engines aro in actual operation together, as the coal required to make good the losses by radiation from the boiler and steam pipes will haro been added together serernl times in the former case, but should only be taken sccount of once. It can be practically determined from the abore data, and can be further cliecked, if an opportunity occurs, by 
slopping all the engines and noting the coal required to maintain the working pressure in the boiler and steam pipes.

When no auxiliary boiler or main boiler specially fitted for sepa. rately supplying tho auxiliary services is fitted, the conl required for most purposes can be determined when in harbour, and, by subtract. ing an estimate formed on this basis from the total expenditure when under way, that for the main engines is obtained.

Another method is to note tho difference in the daily expenditure ander way at low speeds (1) when a particalar ausiliary engino is at work, (2) when it is stopped, all tho other circumstances being as nearly as possiblo the snmo in tho two cases. As, howerer, the disproportion between tho total daily expendituro and that for ono auxiliary engine is considerable, the trials should be repeated threo or four times to obtain reliable results. That this system can be fairly accurate is prored by the fact that separate similar ships hare obtained in this way approximately the same expenditures. A modification of this method is to note the difference between the I.HI.P. doreloped in cases (1) and (2) when the daily expondituro of conl is the same. Knowing this difference and the coal expendituro per I.H.P., an approximate measure of the coal required by the auxiliary engine in question may be obtained. Special caro must bo taken in the measurement of tho I.H.P., and tho trials should be repeated three or four times.

Bs adopting one or the other or all of the abore plans, ressels can approsimate very closcly to tho expendituro for the main engines and to that for tho auxiliary engines as a whole or in detail.

Besides the aboro expenditures there are also somo others which it is necessary to distinguish from them to aroid coufasing comparisons, and which are, therefore, separately accounted for. They include layiug fires and raising stenm, banking fires, waiting orders, and steaming when the speed is so variable that no distance can be logged, as when at target practice; thero is not much dificulty, howerer, in measuring the coal so used with fair accuracy.

Some instances of coal expendituro by war-ships under certain circumstances were giren by Admiral Long in his paper on Cruisers, read in the carly part of this year at the Institution of Naval Architects. 'The following is one of a different character, showing a six montlus' expenditnre incurred by a largo modern battle-ship on ordinary peaco serrice:-

Steaming, making good distance .......... 869

Laying tires, banking fires, steaming when no distance is logged, de.................. 335

Culinary purposes and warming ship ......... 112

Distilling for ship and boilers .............. 481

Electric lighting ..................... 554

Otber anxiliary purposes, as stecring, pumpiug, working guns and torpedoes, rentilating, workshops, \&c.......................... 211

These serrices comprise four short passages of about 70 knots each 
and one of about 500 knots at moderatels stendy revolntions per ninate; onc passage of 500 knots at revolutions varyiug from 61 to 97 per minute, this including quarterly passage trials; 14 dajs' cruising at from 4 to 12 knots orer 2,000 knots, with occasional stoppages; threo occasions specially under way for target practico; one olectric light cngino in usc coustantly throughout the whole period, generating a current of from 260 to 410 amperres; a secoud electric light engine in uso occosionally a few honrs at a timo; 1,950 tons of water distilled for ship purposes; and the usual ventilating, pumping, and other minor ausiliary machinery in daily use.

Dering war serrico the expenditure would probabls bo much increased, but rould entircly depend on the service required. If called upon to steam long at high rates of speed, the increase rould bo rery great, and coaling would hare frequently to be resorted to. It would also be increased, but not nearly to the same extent, if called upon to steam for long periods at a low speed; as this is a rery probable demand that will be made, tho question is considered in some detail later on.

We now proceed to an analysis of the sereral serrices in greater detail, and begin with the main engines, whose object is the propulsion of the ship. The coal expended and power developed by theso engines hare been determined, in most ships, from delinite experiments for the purpose, as well as from the ordinary occasions on which a steady speed has been maintained. The performauce in a particular case may be gircn, that of a large battle-ship, as rery full and reliablo data have becu obtained under definite conditions, and the engines are representative of a large number of recent constraction. The following are the expenditures of coal per hour per I.H.P.:-

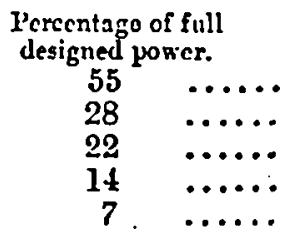

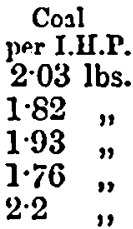

There hare been more economical results than these, at somo of the powers, from engines of the same type, and also some morse, the expenditure being materially affected by sereral circumstances such as quality of coal, differences in details of construction, and differences in managemeut. The abore figures, howerer, may be taken as a fair performauce nuder good conditions.

Tho engines of the ship in question are of the tri-compound type, which, in the Royal Nars, is the most advaneed type of engine. Its principal claracteristic is cconomy of fuel, and its adoption has been fouud to hare reduced coal expeuditure for power both at high and low powers to about an avernge of 20 per cent. below that required by bi-compound engiues, and abont 50 per cent. less than that required by simple enginos.

The adrance of the boilers with regard to the economical generation 
of steum has nodfept paco with the engines in the cconomical ase of steam; their advance has, howerer, been very marked in cnabling tho hight pressures required by tho later engines to bo safely obtained. The old, roomy, rectangular, low pressure boiler of $30 \mathrm{lbs}$. per sq. in. enabled a large proportion of heating surface to bo introduced, facilitating the passage of heat from the firc to the water, and also largo furnaces and combustion chambers which allowed the fuel to burn completely and gire out a large proportion of the lieat it was capable of generating. The cylindrical forms necessitated by high pressures, now up to 15 5 lbs. per sq. in., curtailed to some extent these constructive features, and hence there was some falling off in the amonnt of water eraporated by a given quantily of fuel. It has, howerer, been found possible, in some of theso boilers, to get a high degree of cconomy. At moderato powers, rougl measurements made on bonrd H.M.S. "Thunderer" showed an craporation of 9.6 lbs. of water per ponnd of fuel bount, which was very good Welsh coal. There is no donbt, however, that such a resnlt requires both rery good conl and careful stoking. The temperature of tho feed water was about $100^{\circ} \mathrm{F}$., and the boiler pressure $110 \mathrm{lbs}$.

To obtain the best results from the stenm, it is necessary that the cylinders should ho steam jacketed. Stenm jackets nro not ouly of ralue in this respect to tho tri-compound engine, but also to the bi-componnd and simple engines when even $\Omega$ moderate rato of cxpansion takes place in cach cylinder. Tho fitting is generally adopted in tho nerg, and consists of un nnnular chamber, curcloping the cylinder into which steam is admitted and roaintained at a pressure about equal to the maximum acting inside the cylinder itself. This, by imparting heat to the expanding stcam, aids in reducing the amount of stenm liquefied. The benefit derived from these fittings depends upon circumstances, but it has been clearly shown that the amount of power developed by a giveu expenditure of fuel can bo increased 10 per cent. by their use. In practice, the pressure in tho steam jackets must not bo so high as to aroid all liquefaction on the cylinder surfaces, as these surfaces, when worning too dry, requiro a larger amount of oil to keep them efficiently lubri. cated. The objection to this is that a considerable quantity of the oil so used passes with tho working steam into the feed water, and thenco to tho boilers, and increases tho temperature of tho heating surfaces. With this limitation, horrerer, stenin jncketing has froved of cconomical ralue.

A vers important point, peculiar to the engines of a war-ship, is ccononical working at reduced speeds, and this point will be dealt with somewhat fully. The preriously mentioned battle-ship areraged, on the runs made during six months, a speud of 8.6 knots, which is abore the average of most other vessels. This speed corresponds to an I.II.I. of 1,300 , smooth water and clcan bottom; tho actual avernge I.H.P. would be greater than this on general service. The "ordinary speed" of such a ressel is $9 \frac{1}{2}$ knots, corresponding to 1,800 I.H.P., and the most economical specd wonld probably be near 5 knots, 900 I.H.P. 


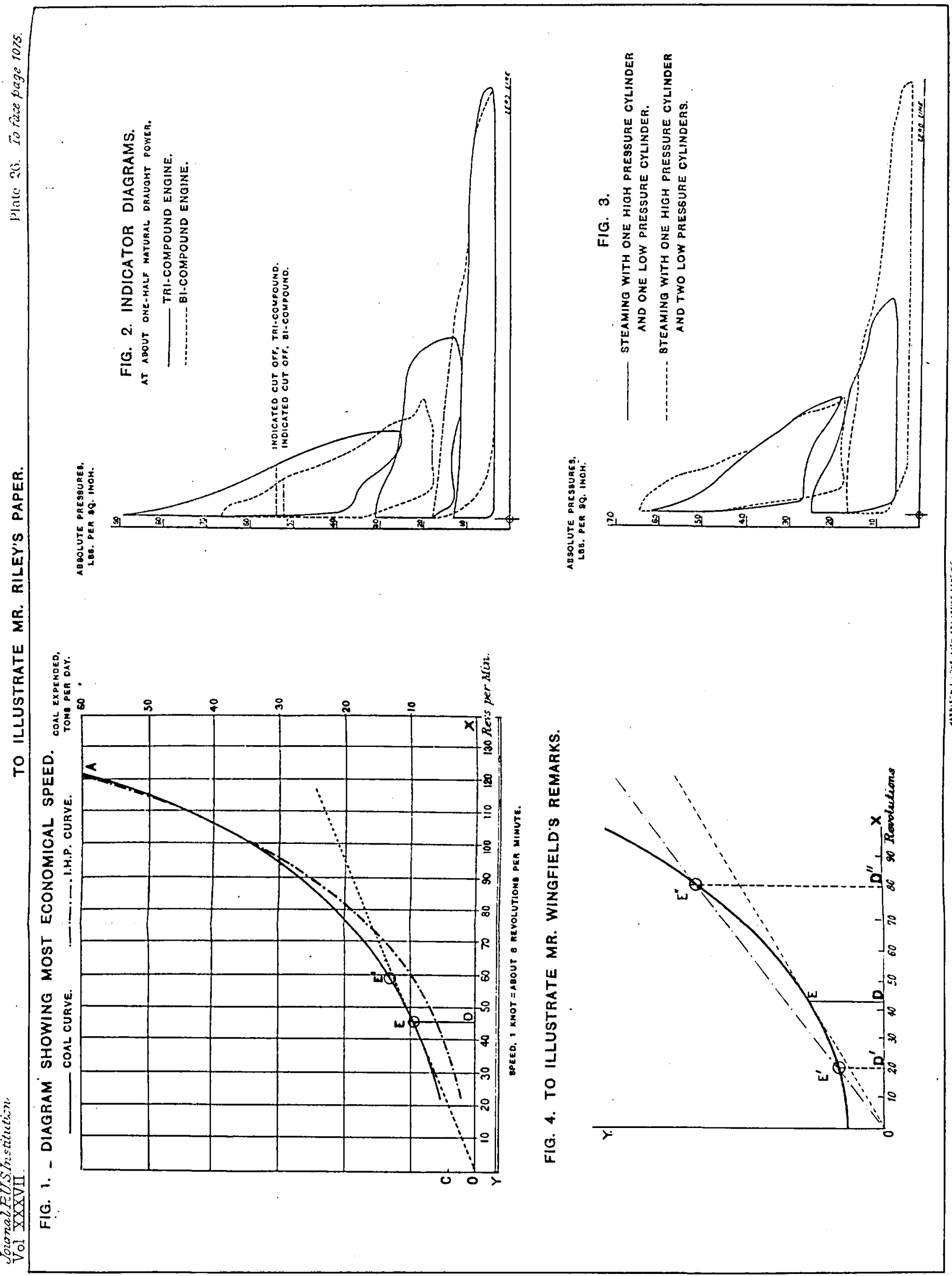


The low averago speed is partly the conscquerice of the greater distanco made good per ton of coal at low specds than at high speeds, and partly because the nature of the geueral service does not demand $a$ high speed. The cause of the increased cconomy for distance at low speeds is, no doubt, well understood, and all that need be done hero is to draw attention to some of the sea specds and consumptions determined at sen in tho battle-ship in question, and which are as follows :-

\begin{tabular}{|c|c|c|c|c|}
\hline I.II.P. & Specd. & $\begin{array}{l}\text { Rerolutions } \\
\text { per minute. }\end{array}$ & $\begin{array}{l}\text { Cosl per } \\
\text { das. }\end{array}$ & $\begin{array}{l}\text { Knots pcr ton } \\
\text { of coal. }\end{array}$ \\
\hline $\begin{array}{r}\mathbf{7 , 2 2 0} \\
\mathbf{3 , 6 0 0} \\
2,870 \\
1,810 \\
900\end{array}$ & $\begin{array}{c}13 \cdot 66 \\
10 \cdot 9 \\
0 \cdot 92 \\
8 \cdot 96 \\
6 \cdot 97\end{array}$ & $\begin{array}{l}63 \cdot 6 \\
63 \cdot 1 \\
62 \cdot 0 \\
51 \cdot 2 \\
11 \cdot 2\end{array}$ & $\begin{array}{r}\text { tons. } \\
157 \cdot 3 \\
70 \cdot 4 \\
59 \cdot 6 \\
34 \cdot 3 \\
21 \cdot 6\end{array}$ & $\begin{array}{l}2 \cdot 03 \\
3 \cdot 5 \\
4 \cdot 0 \\
6 \cdot 2 \\
7 \cdot 3\end{array}$ \\
\hline
\end{tabular}

The knots mado good per ton of conl show the superiority of the lower specds in ecooomy of fuel, this arising from tho bight rato at which the power increases in comparison with the increase of speed.

An important point in connection with this qnestion is that if the speed bo reduced below a certain point the distance covered by the expenditnro of a ton of coal decreases. Tho specd at which this change takes place is termed the " most cconomical speed," and is of serrice when the chief consileration is to steam the greatest distance for a given quantity of coal. It is always $\Omega$ rery low speed; is rarely higher than that corresponding to 12 per cent. of the full forecd-draught I.H.P., and in some ressels which have a vers large proportion of power for their displacement the I.H.I. for most economical speed is a much lower proportion.

The natare of this speed and tho circumstances affecting it can best be examined by means of a diagram, which is given on Fig. 1. The horizontal line OX represents the speed in knots per hour or the number of rerolutions ennde by tho engines per uninate; the rertical line, quantity of conl expended in tons per das; the curre AE represents the expenditure of coal jer day for any particnlar number of revolutions or speed. To constrnct this curve a number of actual runs mast be made at rarions specds, and tho coal expenditure carefully measured in ench caso; the points represeuting the results are plotted off on the diagram, and a fair curre drawn tbrough them. It will bo found that a peculiarity of this curro is that if produced to the zero speed it will cut the line $O Y$ at some point, $C$, some distance from $O$, the distanco $O C$ representing the expendituro neressary to countcract the effects of zndiation of heat from engines and boilers. The most economical speed and the consumption are represented by the point $F$, where the tangent drawn from $O$. touclies the curre $A B$, $O D$ representing. 
tho speed and DE the consumption. That this is so follows from the consideration that the most cennomical speed must be that where $\frac{\mathrm{ED}}{\mathrm{D} \overline{\mathrm{O}}}$ or $\frac{\text { expenditure }}{\text { speed }}$ is least. This ralue is constant for all points on the line $\mathrm{OE}$, and is greater for all points aboro $\mathrm{OE}$, that is, all other points on the curve $\mathrm{AB}$ represent a higher consumption for distance than the point $E$. Ono raluo of this method is that it is readily scen that for a wide range of speed about $\mathbb{E}$ the increase in expenditure is very trifling, the present figure showing that the speed may range from 30 to 60 revolntions, or 4 knots to $7 \frac{1}{2}$ knots, withont any considerable variation in the economy. In practice, it nill generally be more desirable to steam at the higher specd, riz., $7 \frac{1}{2}$ i:nots in the case considered, and this may be done without incurring any appreciable waste of fuel. The most economical speed varies with altered circamstances of weather, bat when a series has been obtained under definite similar conditions they may bo plotted out in tho same way.

Also, in cases whero it is necessary, with a giren amount of coal on board, to steam the preatest distance with it, the coal used for the necessary auxiliary scrvices must be taken into account, and can bo represented on the diagram by drawing a line YY.', distant OY, equal to the auxiliary expenditure per day. The "most economical speed" must be obtaiued by drawing the tangent to $A B$ through the point $Y$, which gires a speed greater than that obtained when the auriliary services are not taken into account.

If this coal curvo be closely examined in comparison with tho I.H.P. curre, one or two important points will be noticed. Starting from tho higher speeds, the I.H.P. curre falls rapidly as the speeds decrease until low specds arc reiched, when the fall is less rapid, and at very low speeds indeed approach the direct proportion to the speeds as the influence of the constant cugine friction becomes predominant. At high and moderate speeds, the coal curve approximates to the power cuire, but falls less rapidly at the lower sueeds, being affected by the amount of steam nocessary to orcrcome the back pressure on the lor pressure pistons and by the heat lost by radiation, tho former being practically coustant at all speeds and the latter constant if the same number of boilers bo in use. 'lliese tro sources of waste play an important part in increasing the quautity of steam uscd per I.H.P. at low specds.

To reduce the rate of this incrense as much as possible is one of the considerations that has led to the adoption of a lower ratio of volumes of the low and high pressuro cylinders than is tho practico in the merchant scivice, although this entails somo sacrifice of economy at the higher speeds. The case quoted will shoir that a high degree of economy at eren very low powers can be obtained from such engines. 'The proportion of eslinder rolumes adopted for tricompound engines of war-ships arerages, nbout, high pressure, 1 ; iutcrmediate pressure, $2 \frac{1}{4}$; low pressure, 5 ; while for similar engines of merchant ships it is not infrequently $1,23,7$. 
To obtain the best results nt low powers, it is most essential that the reduction of the power should be obtained, as far as possible, by increasing the rato of expansion, thus supplying the steam to the high pressure cylinder at a high pressure and cutting off the supply at au earlier part of the piston's stroke; tho jacket pressures, within the limits already roforred to, being 80 adjusted as to aroid nnnecessary liquefaction. When steam at the full boiler pressure is admitted to the cylinder and tho carliest practicable cut-off employed, the engines still derclop a comparatirely high power, and any further reduction must be effected by throttling the stenm or reducing the pressure in the boilers. Tho latter is the preferable plan, but cannot be reduced below that necessary to promptly bandlo the main engines and to work tho anxiliary engines.

As an illustration of how the adrantages peculiar to a more advanced tspo of engine may be lost, tho indicator diagrams in Fig. 2 are given. These are combined in the simplest way for the sale of a moro ready comparison, and represent one set of three from a tricompound engine, $130 \mathrm{lbs}$. boiler pressure, and ono set of two from a bi-compound engine, $60 \mathrm{lbs}$. boiler pressure, both engines working at about 60 per cent. of their natural draught purrer. 'I'he difference between them is chicfly that a much later cut-off in the high pressure engine was adopted with the tri-conpound engine, resulting in reducing the total ratio of expansion to less than in the bi-compound engine; there are nlso eridences of greater liquefaction. The tricompound area, which represents the work done per stroke, is rather greater than that of the bi-compound; but the quantity of steam used, as indicated on the diagrams, is also as much greater as to make the economy of steam practically the same in each case, while the actnal consumption of fuel per I.HI.P. was slightly greater with the tri-compound. This engine, when worked with an carlier cut-off and steam in the cylinder jackets, has a substantial advantage in cconomy orer the particular bi-compound engine referred to.

In the "Blake" aud "Blenheim," whose engines are designed to derclop exceptionalls iigh powers, special arrangements havo been mado to keep down the coal expendituro at very low powers, and consist, as is generally known, in fitting two separnte sets of engine:s to cach of the two propeller shafts. In peace-time, it was intended that the forward engines should be disconnected, and the two after ones alone used. Thus, when steaming at a comparatively low rate of speed with the after engincs ouly, the proportion of the corresponding I.H.P. to the full powrer would bo lialf what it would be if all tho engines wero in use. From experience with the "Mlake" under the two conditions, tho consequent reduction in coal expendituro per knot at 9.6 knots bas prozed to bo substantial.

In some ships the maximam power of the engines during peace service has been reduced by fitting a special slido ralre with increased lap to the high pressure engines, the eccentrics being suitablyadjusted. This arrangement has only been applied to some recent ships, and sufficient experience has not jet been obtained to show tho effect on the economy of steam. 
With regard to adapting the boilers to low speed stcaming, the subdivision into several boilers, necessary in most ships from other considemtions, euables the boiler power to be properly proportioned over a large range to the actual power to be developed by the engines. The usual conditions' of men-of-war steaming, however, render it generally necessary to bare steam up in a greater number of boilers than is required to derclop the arerago I.HI.P. economically, as the variation in revolntions and auxiliary work above referred to demands that steam should be quickly arailable for the maximum requirements. This not only iucreases the waste arising from radiation, but also from the irregalar firing necessary to weet the rarying demands of the engines.

When the number of boilers in use is much abore the average requirements of the engines, and the maximum is not wanted to bo excrted too suddenly, recourse is frequently had to the reduction of tho grato area. This, by increasing the proportion of heating smrface to grate area, and by affording a larger space for the combustion of the coal gascs, tends to greater econorny. This reduction of grato can bo rendily effected by allowing the back bars to becomo clinkered orer, or, in some cases, the service reuders it possible to brick over these bars; rertical plates have also been used, placed in tho ash pits transrersely so as to provent air having access to tho length of fro bars behind, and haro been found to be bencficial in some cases.

It has often becn suggested that, at low powers, the ase of only one engine and screw of a twin-screw ship might bo more economical than using both engines. This has becn tried by manj ships, with the result that, down to powers as low as 10 per cent. of the natamal draught power, there is no saving of fuel, and often a sulustantial loss. These show that the falling off in speed cnused by the resistance of the rudder and idlo screw is so great as to more thau counteract the increased efleiency produced by developing the wholo of the power in ono engine, and the reduced waste cnused by the elimination of the engine resistance and back pressure of the engine which is stopped. In most of the trials the idle screws were not disconnected froun tho engines, but, if they had been, there is sufficient experience to make it probable that they would not have revolved at that power, and tho practico is also open to the strong objection that tho control of the ship is seriously impaired. An average result from a battle-ship may be quoted, where tho one-tenth I.H.P. was 900, the speed with two screws 6.8 knots, the speed with one screw 5.3 knots, the distance mado good per ton of coal with two screws $7 \frac{1}{2}$ knots, and that for ono screw $5+$ knots. The percentage of loss was therefore 30, and a reduced speed of $1 \frac{1}{2}$ knots into the bargain. $\Delta t$ higher specds the single screw method is still more unfarourable.

There i.zro been a few cases where some econong has been obtained at from 3 to 5 per cent. of the natural draught power; due apparently to the circumsiance that at extremely low powers the inefficiency of the engines mpidly increnses. The corresponding speed is, however, so low that it may be doubted whether it would prove of any practical valne. Even at theso low powers it rould 
appear that tho cconomy is lafgely dependent upon conditious of weather, and if economs were proved in a giren ship under certain circumstances, it would probably disappear if the circumstances were eren slightly altered.

A proposal has been made to disconnect the L.P. cylinder of a triple expansion engino at low powers, and thus derelop a higher proportion of fall power, say 30 per cent. in a bi-compound exgine of cรlinder ratio $2 \frac{1}{4}: \mathrm{l}$, instead of 20 per ccnt. in a tri-compound engino of double that ratio. This proposal is based, howerer, on the supposition that tho loss of efficiency of tri-compound engines is very great at low powers; but experience generally in the navs engines, including tho examplo already quoted, shows that, orer a wido range of power, this is not the caso; and that the coal expended per I.H.P. when using all three cylinders is materially below that of a bi-compound engine having a comparatively low ratio of cylinders, although tho low power dereloped is in $n$ somershat higher proportion to tho fall power in the latter case than in tho former. This difference in conl ner I.H.P., in favour of working with three cylinders, is also found to be sufficient to counternct the loss sustained by the engiue friction of the T.P. cylinder, and thus leads to the conclusion that no economical adrantage is to be gained by the adoptiou of the proposal nnder consideration.

An instance of some interest may bo gircn, although it ouly indirectly-bears upon the question. It is, lowerer, a caso wibero a comparatirely low power was dereloped with a cylinder ratio reduced to half the total ratio of the complete engine. 'The ressel referred to had bi-compound engines of the three-cylinder type, one H.P. and two I.P., the total ratio of volnmes being $3 \cdot 72: 1$. One of tho J.P. engines becamo disabled, and tho ship steamed 6,000 knots at abont porrer with only one H.P. and one L.P. cylinder, tho ratios being then $1.86: 1$. Tho practical result was a coal expenditaro per hour per I.H.P. of 3.5 lbs. against 2.4 lbs. whon all cylinders were in use, dereloping tho same power. Indicator diagrams to show tho distribation of steam when using two cylinders are giren in Fig. 3, and also, for comparison, a set when using about the same quantity of stean per stroko when all engines were in ase. These show that part of the increased coal expenditure was due to increase of back pressure, due apparently in some measuro to the whole of the steam entering at one end of tho condenser; bat, making an allowance for this, the expenditare of steam was much grcater than when using tho whole of tho engines.

Tho coal expendituro for auxiliary purposes is a very material itcm in war-ships compared with tho quantity used for propulsion: In the course of a year the larger modern ships generally burn as mucl or more for the first as the last; this is partly absolute, on account of the increase in the number of auxiliary services for which coal is used, and partly relative, on ascount of the low arernge spect and timo under way, as compared with a merchant steamer. The proportion becomes considerably lessened in the case of a passago at a fairly high power, say at half tho full power, the proportion between 
tho coal for auxiliary services and that for propulsion bcing then about 9 per cent.

T'o afford an idea of the magnitude of the auxiliary engines on board a modern ship, it may be stated that on ove of the most im. portant there are 58 distinct engines, not including boat engines, tho I.II.I. amounting in the aggregnte to quite 2,000. This, if contiuuousls dereloped, wonld mean an cnormous expenditure and considerably besond what is actually incurred. As a matter of fact, sereral of these engines are only duplicates of others, and ronld not be used at the same time with them; and manj are ouly used intermittently.

It should be mentioned hero that the auxiliary engines here referrel to are only those which are used for parposes distinct from propulsion. The coal expenditure for such engines as the main circulating engines, main feed engines, and starting cngines is included with that for propulsion. Many of the auxiliary engines do not lend thernsclres to economical working, as some aro necessarily so far remored from the source of steam that considerable condensation takes place in transit, also they receire their stenm supply at a reduecd pressure and exhaust it against a comparatively high pressure. The work of somo is of such a clinracter that it is impossiblo to emplos any materinl degree of expansion or to compond the cylinders. To obtain tho greatest economy possible, thoso which enn be so treated are compounded, and also a separate auxiliary boiler is fitted where one of the main boilers is too largo for the rork; or, in some cases where the main boilers are of the doable-ended type, for one of these, two single-ended boilers have been substituted.

The electric light engines deservo special consideration, ns one or moro are in use in many ships practically all tho year round, and necessitate, consequently, a considerable total expendituro of coal. These are now made, and havo been for some jears past, on the compound priuciple, and a rery early cut-off employed in the high pressure cylinders, thus allowing of a high total rato of expension. Every engine is tricd carefully at a Government dockyard to determine the quantity of steam it consumes, and a certain standard of economy must be attained. Theso trials afford some usefal facts as to their consumption under the trial conditions, but, as will be supposed, this will bo subject to some modification when in uso on board ship. On these trinls no account is taken of the steam used by the feed pump, nor of the condensation which takes place in long leads of steam pipe, nor of tho amount of coal used when fires are cleaned. With regard to the condensation in steam pipes, it is found on the trials on shore of the clectric light engines that an amount of water is collected at the engine end of the supply pipo to the extent. of 7 . to 13 per cent. of the total steam used, although the length of pipe is comparatircly short and is well lagged.

A case of the expenditures on board a battle-ship and on trial in the dockfard may be quoted; tho steam consuiniption on trial was found to bo for one electric light engine generating a current of 400 ampères such as to requiro a daily expendituro of $2 \cdot 6$ tons of 
Welsh conl of good areragaquality. The reported expenditure from the ship is 3 tons per day; and the namber of lights in use such as to require from one half to the fall power of one engine. 'The case of "Warspite," 8,400 tons displncement, especinlly mentioned by Admiral Long, in his recent paper, showed an expenditure for lighting on passage out to ner station of orer 4-tons per day. This amount was perhaps larger than that really used, insufficient opportunities haring occurred to enable it to bo accurately deterznined. Later results showed an expenditure of about 3 tons and less per day, a reduction probably assisted by cconomy in the number of lights and length of time in use. The reduced expenditure, however, does not appear excessire when it is considered that the engines are of the simple type.

Distillation of sea water is also an important item of coal expenditure. On a large ship fresh water is often required to the ertent of about 12 tons pcr day for drinking, cooking, and washing, and abont $\frac{1}{4}$ ton of water per tou of conl burnt in the boilers to make up losecs of steam and water from the boilers, engines, pipes, joints, valres, ic. ' Both of these amounts are of a rery elastic nature, and in many cases it has becn found possible to materinlly reduce them below these figures. When direct distillation from tho boilcrs was cmplojed, as in tho older ships, a rery fair return was obtained for 1 ton of coal, areraging about $7 \frac{1}{2}$ to 8 tons of fresh water. When, to aroid large quantities of scale being deposited in the boilers, doublo distillers were adopted, the quantity of fresl water obtained for 1 ton of conl was reduced to about 5 to $5 \frac{1}{3}$, the loss resulting principally from condensation of primary steam on its way to the evaporator and to the high temperature it possessed when escaping as water from the eraporator. Compound double distillers were tried and found to result in a considerable gain in the quantity of water produced for a given expenditure of fael, and in recent ships a pair of doublo distillers is so fitted that they may be worked in this way. It is arranged, howerer, that each distiller can be worked eeparately when argency requires the greatest output to be made. It may be said here, in connection with this point, that it not infrequently happens that economy of fuel and economy of wcight and space do not go together, and lience, iv a man-of-war, where economy of weight and space is of such im. portance, economy of fuel must often to some extent be sacrificed.

Under some circumstances of naval work, cconomy of coal may be of such imporlance that, beyond working the machinery so as to fulfil its services with the least expenditure of coal, it inay be desirable and possible to dispense with some of them altogether. Tho character of the work must determine which of them can be dispensed with, but thoso which appear to lend themselves to this are the stcering and electric lighting cngines. Both of these use up considerable quantities of coal, which can be saved for other purposes by steering with the hand gear and using oil and candles for lighting purposes.

The exact advantugo to be gained by this courso depends apan tho service, and is greater the slower the rate of speed. A large.cruiser,

roL. IXXVII. 4 E 
edy, carries 1,000 tons of coal; at 10 knots speed under good conditions this witl carry her, with all tho ordinars anxiliary purposes in use, abont 7,700 knots; if the stenm stcering and electric lighting engines be stopped, she will be able to cover about 8,700 knots, a gain in distance of 1,000 knots, or $\frac{1}{6}$ th more. $\Lambda$ t a high power, say, 60 per cent. of tho natural draught, sho may steam about 3,000 knots in the one case, and 3,100 in the other, the gain in distance being only 100 knots, or $\frac{1}{3}$ th more.

Before concluding this paper, the promress of the coal question may be illastrated by giving some particulars of the passage of three vessels, fitted with progressive types of machinery, out to the same distant station. The first had simple engines and very littlo auxiliary machinery, and steamed the distance of 7,052 knots at an areringe specd of 5.5 knots; 1,575 knots wero mado under steam only, 5,071 nuder steam and sail, and 436 under sail only; the total coal expenditure was $1,0.16$ tons. 'Tho effect in this case of using sail power when steaming, besides increasing the speed $1 \frac{1}{4}$ knots, was to reduce the coal expenditure per knot to less than ono half what it was when the ressel was under steam only. The second ressel had bi-compound engines, boiler pressure $90 \mathrm{lbs}$. per sq. in., was fitted with $n$ large amount of auxiliary machinery up to modern requirements, and stcamed 6,985 knots at an nverage speed of $7 \cdot 7$ knots, with a total coal expenditure of 1,533 tons; this includes a considerable fraction for tho main engines for purposes other than making good distance. The third vessel, a now ship, it is estimated from actual experienco with similar types of engines, triple componnd, 155 lbs. steam pressure, will steam the distance of 7,000 knots for 1,200 tons of coal at an avcrago speed of $12 \frac{1}{4}$ knots. To afford an idea of the comparativo power to propel these ships, it may be stated that the H.P.'s required to drire them at 10 knots per honr are respectircly $1,500,1,500$, and 1,350 , smooth water and clean bottoms.

The first two cases showed a very material reduction in the coal expenditure for power developed in favour of the bi-coinpound cngine; but the total amount of coal went up considerably. This is almost fully accounted for by the facts that she had no help from sails, steaned at a highur average speed, and had a greatly increased amount of auxiliary machinery in use. The oxpenditure for the tricompound engines should show a still farther cconomy for work done, bat it is not likcly that tho total expenditure will fall bclow that of the ship fitted with simple engines, on account of the very mach larger amount of work to be performed by tho machinery.

A review of some of the remarks in this paper will show that mach has been done in the construction of the machinery of war-ships to cnable econumy of fuel to be obtained, but that the realization of this economy depends materially upon its uso and treatment on actual service. So great is the influence of the latter, that improved treatment has been known to hare nearly doubled the radius of action of a vessel that was obtained when the treatment was not so satisfactory. Some difficaltics in the way of economical working haro been considered, and it has been shown that the principal of these can be over- 
come to such an cxtont is to obtain good results on actunl service. Many of theso difficultics aro sach as to be out of the control of ofticers in chargo of the machiners, and it is in these respects that ofticers in command of ships mas exerciso matcrial influence on coal expenditure, especially in knch matters as economy in tho uso of auriliary services and in steady rauning, and generally in tho encouragement of those under them to uso overg effort to keep down expenditure to the lowest limit consistent with efficiency.

Mr. Wixcriec : I harc becn rery much struck with the ingenuity of the dingraus, which are catircly new to me, showing a rerg simple method of finding out from a scries of trials the intervals between those cxperiments at which the ehip rould be steaming at the most economical ratc. Diagrums aro alirass worc sutisfactory for taking arcrages than simple arithmetic. Fou may approximate by an ordinary arerage, but if the experiments are rcliable, jou can get the absolutcly correct point by meuns of a diagram, and I must congratulate tho nuthor upon tho rers ingenious arrangenient that he has hit upon. 3ir. Barnobj lias just iuformed we that an American engineer, Mrr. Hollis, has pointed out that there are two epecds at which the eame economy is realized, and I ece this disgram also clearly shows this to be a fact if the ship is not ruming at precisely the most economical specd. For instance, if the engincs are running at 20 rerolutions, the cosl consumption is shown on the figure by $\mathrm{E}^{\prime} \mathrm{D}^{\prime} .{ }^{3} A$ line drarn through $\mathrm{O}$ and $\mathrm{E}^{\prime}$ will, if produced, cut the curre again at $\mathrm{E}^{\prime \prime}$, which is perpendicularly abore 80 rerolutions on the scalc. The author has pointed out that, at any point on such a line as this, sou ure burning the eame coal per natutical inile, hence a giren distance cau be run by the ship, whoso performunce is represented by this diagram, with the same reight of coals, whether running at 20 or at 80 rcrolutions. 'Iliat is, the distance will bo done in one-fourth the time at the higher speed, witliont any larger erpenditure of conl. It is erident then that, if not quite sure rhat is the most economical speed, it is better to err on the fast side rather than on the slow, and, when cruising, orders sliould be giren to run as near the cconomical speed as poszible, but nerer at a lese speed unless circumstanecs require it. Wlicnerer a ship runs at a specd less than that of inarimum cconom, sho is wasting timo as thero is another higher specd of cqual economs. I think the great importance of this fact is self-evident. The coal per nautical mile $=\mathrm{DE} / 2.4 D O$; as the triangles 1$)^{\prime} \mathrm{E}^{\prime} \mathrm{O}$ and $\mathrm{D}^{\prime \prime} \mathrm{E}^{\prime \prime} \mathrm{O}$ are eimilar, it is crident that, as stated abore, all points, such as $\mathrm{E}^{\prime}, \mathrm{E}^{\prime \prime}$ on the slant line, represent cqual weights per nautical mile, or cqual radii of action for a gircn weight of conl burnt. The distance run per ton of conl is, of course, $2 . \frac{\mathrm{OD}}{\mathrm{D}) \mathrm{F}}$. There is one littlo point about the mole of action of the steam jacket. I think thero aro rery few people who hare 8 : : adied the stean engine who doubt the great econony of ten realized by the uso of the jacket. Opinions differ, howerer, as to the cause of this econony. I ece the author speaks of the jacket inporting lieat to the steam. I doubt if it is possible for the joclset to heat the steam much, if ut all, cxcept, of course, the rers emall proportion of the steam wbich happens to be in actual con. tact with the eides of the cylinder. The innker of superheating apparatus know this so well that they use small tubcs, so as to cause as much of the steain to come in contact with the metal as possible. A very rougl analogs mas be found in the following hypothetical case:- Suppose re imagine an inclined plane made of somo nboorbcat material, such as blotting puper. $\hat{\Lambda}$ current of air is passing under it, and kccps it dry, so that a drop of rater, if Ict full on the upper surface, will sink in "rị be dricd up almost instantancously. A number of bubbles are now poured ou to the upper end of tho plase, and nre ullowed to roll down it and of at the lower cnd. It is an object to eccure as mnny bubbles at the end as possible out of the total number poured on. Is the blotting puper is kept drs bs the current of air

I A fgure illustrative of Mr. Wingfield's remarks will be found in Plate 26.Ediroz. 
beneath it, those bubbles next it will burst and make was for another lajer, which will also hurst, and, the moisturo being conducted amaj through the absorbent surface, laser after lajer is destrosch. Only those bubbles touching the surface are, howerer, affected, and a certain percentago glide orer them, and are caught as they fall from the lower end of the plane. These bubbles may be tilien to remotely rescmble tho molecules of stcam in their action, if heat is substituted for moisture. The lajer of stcaun molecules next the cooler ejlinder walls is condensed on cntering the cylinder, and collapses, maling room for another, and so on, but the steam in the centre of the cjlinder is not affected. Torcturn to the bubbles. Since the drjncss (coldness) of the surface causes their collapsc (condensation), it is crident that water (heat) wust be substituted for the current of nir (rudintion and conduction). When the surfuce is thus kept moist (hot) the larer of bubbles (steam molcculcs) next it do not collapse, and serre as a cushion to feep the others from contact. A much Inrger proportion of the bubbles (steam) reniains, therefore, at the ead of the inclined plane (point of cut-off). IIere, again, it is only the laser of bubbles (steam) next the surface which is dircetly aficeted; the rest is indirectls affectcd, as it is lept from contact by the uncollapscd (uncondersed) cushion of bubbles (steam). In the case of the engine, the jaclet laring done its work by lecping tho sides of cylinder free from rater, the loss during expansion. due to re-eraporation, docs not tale place. It is sometimes supposcd thut great losscs occur from the exliaust steaun conducting licat from the jackets. Stcam is too poor a conductor to do this. Water will, and the jackets should be bot enough to prercat its accumuletion before cxpunsion commences. To sum up: the great gain derired from jackets is by prerenting condensation and eubsequent craporation on tho oides of the cylinder, and not by licating the mass of stcam lowing into he cylinder. It follons that jackets are of most use where, as in small engirces, the aren of the sides bears a large proportion to the cubic capacity of the cylinders. In conclusion, I wish again to express my rers great admiration of tho author's diagram, mhich will, I am sure, bc most uscful.

Mr. Wkite: The concluding sentences of this paper sum up the lessons which should be Icarat from its eludy. The paper rill be of cnormous ralue to tho Serrice afloat. It is not mercly a remarkable collection of illustrative examples of causes affecting coal cxpenditure, but contains also rery raluable suggestions as to means whereby econonies may be effected. Mr. Riley has made this matter one of the closest study. The paper mill be circulated throughout the fleet in the Journal of this Institution, and I beliese that it will lead to considerable practical beneft both to tlic Serrice and outsido tbe Scrrice. Wlien re liare it shown that by means of greater skill or experience in management the radius of action for a giren conl suppls mas be doubled, wo can sce how important it is that both officers in command and those in charge of the engine room stafl shall bnow in what direction to work in order to obtain cconoms. IIr. Riley docs not mako speculatirc etalements, but deals with records of fact. In the eawe ship, at different periods of service, he shows that the radius of action has becn doubled by sarings duc to better management alone. If I maj renture to emplasize the statement made by Mr. Kilej, I should wish to dwcll unon the increascd expenditure which maj be inrolred in rapid rarintions of epeed, or in uncertainty as to specd, or in the extended usc of auriliars ecrrices of rarious kinds. Sensible cconomics in cosl may bo effected by commanding officers if they ect thempelres the task of assisting enginecs officers os much as possible. When I was alout in the manaurres of 18S9, I made as close a study as I could of the conditions obtaining in a equadron on ecrricc. In that dirision of the lect in which I was cmbarked, when re wero at ateam tactics at 8 knots, erers ship had steam ready for at least 10 knots. Sometincs, in watching the inanourres, I found sbips rere moring for a time at as high a specd as 12 lnots in order to loep station. But the arerage specd of the tactical morcnicnts wias only 8 knots. Clewrly, buch a command of stcam and spced is absolutely necessary when a flect is performing crolutions. Mr. Kiley has well pointed out that thero are conditions of ecrice Fben considerstions of economy in coal expenditure must gire way to other considerations. But when a resel is procceding independently on a İong roragc, by suitable arrangements much may be done in the way of coal economy. Tale the illustration Mrr. Riley gires of what 
nas be done by stopping the electric light, or the steam otecring. The latter plan of course involrcs sone nore manual labour, but I haro been pors than once on board a battle-ship which was stcered with perfect case and success in making a peasage by manual poric?. To show what can bo done, I may add that in the cuso of the "Blake" or "Blenlıeim" the ship was otecred by hand up to a speed of 18 knots. It is much more conrenient, no doubt, to hare one or tro men only at a slesm stecring whecl, rather than many men at tho hand stcering whecl. But if economs of coal in making passages is aimed at, then in these, and in mans other ways which Mr. Rilcy hins hinted at, rery much may be done. I do not desire to my more on this ocension, becnuse my hope in coming was to hear the opinion of naral officers; but baring closcly read this puper, I nuat rencat the opinion that it is one of great practical ralue to the Ninral Serrice. That raluo will be manifest more and more when the puper comes to be studicd by officers afloat.

Admiral CoLoy日 : Is naral officers are called upon to say something, I may say - word or tro, because Jir. Riley is an old shipmate of mine, and I lare no doubt that in times gone by we hare talked orer theso questions in their carlier stages. There are one or two malters I am reminded of, - for instance, the economy of using one of two screxs. I do not know whether Mrr. Riley has dats to show how tho economs of using a single screw rarics according to the direction of the wind. I do not know how it may be with the more recent classes of ships, but with the older clasecs of twin scrers that I lad to do with it was alnost inrariubly found that when the wind blew 3 or 4 points on the bow, the ceonomy of using the weather screr rose considerably orer what the uec of one ecrew did for instance when the wind was right ahead. The eflect of the cliange of wind in that was was to re. quire the ship, supposing she had been using the two scress, to carrs rather moro restlier liclm. The use of the single screw effected the purpose $\mathrm{wbich}$ so much weather helm did, and tho consequence was that with the siugle ecrew jou wero able to leep the helm more in mid-ships. I hoped that we should hare had in the peper some remurks on matters which hare been a good deal before us recently strongly belore us in Lord Brasses's "Naral Annual" this jear. I mean tho rexed question of the effect of auriliary eerrices on the radius of action. Com. plaints are raised, I do not think mysclf properly raised, that the radius of action giren in the tables reprezents a grester radius than really exists on account of the auxiliary eugines. But it seems to me that what is wanted in the Scrrice is somo gort of factor, some sort of dirisor which would discount the figurcs giren, which I understand hare simply to do with the powers of propulsion of the engines -ithout taking anything clsc into account, - that if, corresponding to the differcat classes of ships, some discounting figure could be giren, it would be always eass to tell at once what amount of deduction must be made from the nominal radius $\mathrm{cf}$ action. I rery mucls agree with IIr. White as to this paper bcing of the greate:t possible ralue to the Serrice. I told my friend, on entering, that I had read the greater part of it and that it was a paper which could not proroke much discussion in this theatre, but that it certainly rould prorols in the Serrice a grcat deal of rery useful thought. I am glad to hear Mr. White attack t!ns too great uso of machiners on board ship. Where man-poner is capable of doing the rork I can. not help thinking it is rers much better on bourd war-ships that the man-power should do it. I used to bn made rery low in my spirits with watching the inacliners reighing tbe anchor when there ras plenty of man-power to hare done it, and the mass of man-power was looking on idly at the machine. In the saine way with steering. It would be better for the Service if machinery should only be used for those purposec for which it is absolutely necessars, and that we should fall back on the muscular porer which re are bound to hare on bonrd for figating purposeg so far as it can possibly be used. I must congratulate BIr. Kiles on the exccllence of the paper he las produced.

Mr. IrIVeusedoE, R.N.: I ghould like to point out a means of testing the accuracy with which coul has becu ineasurcd. Suppose the II.P. is constunt throughout the trial, theu, if a line of coal consumption be plotted of rhich the "abscis:a" is the total time and the "ordinate" the total coal used, the line should be a straight line; but if any crror has becn mado in couatine the number or reight of the buckets it would shor itself by an alteration of slope of tho 
straight linc. That method has bcen uacd by the Committco of Afeclanical Engincers, and was found uecful by them. The althior, on pane 3, gires tho result of a specin trial in which the consumption of conl per H.1. wos measured at different pereentares of full power. Professor Unwill, in a lecture to tho Society of Arts, in January, gare curres showing that if the HI.P. was dearcased by decreasing epeed or boiler pressure, the consumption per II.P. was increased at the reduced poner; but if on the other liand tho power was reduced by increasing the expansion the consumption per H.P. decreased. Tbesc results of the author's ecem to fall under the Iatter bead, and this result of Professor Unwin's would support the riew taken by the author that the pomer should be redneed by in. creasing the crpansion. It should be noted that the crpansion should not be so great that the pressure at release in the low pressure cylinder is leso than the sum of the back pressure together with the friction pressure. The expansion should not be carricd on so far that the pressure at releuse in the lon pressure cylinder falls below about 6 lbs., as Mr. Williams gires it, otherwise there will be a loss from excessire expansion. Then with regard to the steam jaclet; the Comnittec appointed by the nechanical engineers recommended that the jacket should bo so adjusted that the etcam at release in the cylinder slrould be dry. This will agreo with the anthor's condition that there should be eone moisture on the sides cluring the stroke, since the release will not occur till about 0.8 to 0.95 of the stroke, and up to that point. the steam will hare contained a certain diminishing anount of moisture. Finally, I should like to ast the author a question. He gires the performance of the "Tbunderer's" boilcrs as $9.6 \mathrm{lbs}$. of water craporated per pound of fucl burnt. To male that information definite, $I$ should like to ask tho temperature of the feed water and the pressure of the boilcr?

H.S.II. Prince Lodis or Jatrexbera: I slinuld like to mate a few remarbs from the point of ricw of captain of a ghip, avd to deal seriatin with a few of the hints nliclt were thrown out, more especially ns regards effecting cconom, in coal by restricting the expenditure for ausiliars purposes. I thouglit tho matter over a great deal when I ras in command of one of those small ships full of engincs, and I camo to the conclusion that really the only point in which you could possibly cffect cconoung ras clectric lighting. Stcering by land is no doubt another point, but it sliould not be forgotten what, to iny mind at least, is the chicf adrantage of etecring by steam, riz.: the rapidits with mhich jou can put the helin orcr to aroid denger. Under certain conditions no cloubt you could stcer equally well by liand, but if you get answhere. within frequented waters, worling in \& equadron or nnything of the sort, I do not sce hor jou could possibly do it. That and clectrio lighting are the only tro items of expenditure which aro pretty woll permanent and constantly recurring, because, after all, the pumping machinery for torpedoes, wcighing, stowing anchurs, and so on, aro internittcnt. As Admirnl Colonib said, as regards weighing the anclior no doubt jou would hare plenty of "beef" to do it without machincrs, but then the question of time comes in. After all I take it you could do a grcat many things by hand in a ship: if sou hare unlimited timo you hare usually plenty oi men to do it. In the "Dreadnought," we could load and trim our turrets by hand; it rould take us about half an hour as agninst fire minutes bs mischiners, and the same argument, I tale it, npplics whererer you use fteam. With regard to the question Admiral Colomb raised about using one screw with the wind on the bow, I tried it and I found it ccrtainls was so. It was the only point where wo could use ono ecrew, I would not eay with adrantage, but where it appeared to me to be really possible to use it. I au mucls struck bj this diagran, lig. 1. I assume that the uuthor is the originator of it; I hare nerer secn it before. It is rers ingenious and also brings out how liffeult it is to narrow down the economical specd. There must be for all practical purposes a large nargin. Of course the faster you can do it for the eame amount the better. After all, the cuptnin of a elip is rather lompered in giring effect to ccononies in coal consumption, on the lines thrown out by Mr. White, for instance. As lio rightly said: in the equadron you must hare an excess of epeed for tactical purposcs and cren for ordinary station-keeping purposes. But, in thes dars, the moment you are awas from the lag tlicre are two conditions: cither jou are told to go to a certain place at a certann epeed, or clsc jou are told to cruiso within certain waters at your 
discretion. Four other instructions tell you that when jou arc cruising jou aro to u=0 what is called the "ordinary soced" accorling to the scale laid down, prorided it is not faster than the most economical epced; 20 that in cither case you are practically ticd down by instructious, apart from the expediencs of using jour most ccononical epeed. I should like to rerert again, for a momeat, to the question of electric lighting. In the "Scout," for esanple, wo wero peculiarly situated. We were the only ship in the Service then litted with accunulator batteries. I was rery much in furour of them after we found out how to work them. MI cngincers were, howerer, not rery fond of them, as it gare them a grcat deal of crtra trouble. I hare nerer been able to clearly satisfy myself tlint it was more cconomical to uso them as far as the coal comsumption went. Practicalls it meant a great deal more. In the Mcditerrancan summer cruise, where you frequently anchored for fire or six dajs, sho was the onls slip in the squadron which put the khole of her fires out on anchoring, and it affected us moro because we had no auriliary boiler. Now besides being ablo to keep the boilers cleaner it reduced the temperature of tho whole ship, and conduced to comfort and cleanliness generally. Lighting bs accumulntors could only be dono by strictly cconomizing lights; we made rigid rules as to the uso of incandescent lights, which worked rery surecesfulls..$^{l}$ is regarls internal lighting generally, it has always etruck me that nowadajs, where formerly you burnt a purser's dip, sou are not Eatisfied uvlcss you hare a 50-caudle porrcr light. Surely there must be come medium between the two. It is all rers well turning night into das, but sou would noraclass turn uight into moro than das itself crer can be. Ify inprcssion is that the incandescent lights are eomerliat reck. lessls used on bourd ship. It reduces their life and means of courso increased cxpenditure of coal. That is a point on which, I am sure, by strict attention and going c:rrefully into it, coal can be econonized rers largels." the figures which Ir. Riley gives are quite extruordinary, as sliowing the difference in the radius and distance with and without the electric light, and thes arc well worthy of consideration. In fact this paper, I think, ought to do in that respect a greit denl of good. I bag to congratulate $\mathrm{M}$. R. Riles on lanring giren us this rerj interesting und suggestire paper.

JIr. WV. II. RILEx : I am rery mucli obligel to the mceting for the way in which they haro receircd my paper. I understood $M$ r. Wingfield to say that lie did not put rers much faith in the ralue of steam jacliets, and ho gare a rers ingenious cxplanation of their action. I know that the action going on inside the steam jacket and in the cylinder is rery much a matter of conjecture, and, therefore, I was careful to confine myscif to cstablished facts. There haro been trials made with maral engines under certain conditions, with and without tho stean jacket in usc, and it lias been shown that steam jactets are of economical ralue. In a particular case I hare in $\mathrm{mJ}$ unind of a bi-compound engine, the steam expanding about three times in each cylinder, the increase in horse-power was quito 10 per cent. With the same erpenditure of fucl. The circumstances under which this trinl was carricd out were of a trustwortlyy cliaracter; and, moreorer, the result is borne out by other cases in which an cqual degree of cconoms was obtained. With regard to the point raised by Admiral Colomb, and confirmed bs Prince Touis of Battenberg, of tho effect of the direction of the rind on coal espenditure rben steaming witl one ecrer of a twin screw ship, I may sas that there hare been sereral cases reported where the change of the wind from the port to the starboard bon, or rice cersá, has turned an cconomical perfornance with onc ecrew into a wasteful one compared with the results obtsined wlycn using both serens. This was one of the circunstances $I$ had in riew when inserting in that part of the paper dealing with this subject that "cconomy is largely dependeut upon conditious of weatler,

1 I asa afraid I strajed rather akay from the point under discussion by mention. ing accumulators. Their ralue laws no doubt been deceased by the nore gencral introduction of ausiliary boilcrs.-Is. 13 .

I I meant to hare added that I do not adrocato any restriction in cosl expenditure for internal lighting, fresh water for cleaning purposes, gencrall 5 , \&c., in times of pesce. Coal is always to bo lind, and its gencrous use for the purposes enumerated undoubtedly adds rastly to the general rell-being on bosrd ship.-L. H. 
\&c." I did not go rery decply into the question of the effect of the auriliary ecrices on the radiwe of action, but the casc I quoted I thought would bo suflicient to show whit was the effect in the special cases of the stecring engino and the electric light. Any onc mas, from the diagram, Fig. 1, and knowing tho total quantity of coal that can be carried, find what is the radius of action for cach speed. This diagram represcats $8 \mathrm{n}$ actual case, ond gires tho specd, the tons of coal erpended per lay for ateaming, and also that fur auriliary purposes, and from these particulars other curres of radius of action can be plotted which would at once indicate the effect of the coal expended for auriliary purposes. Mr. Lirersedge anticipates that the economy at reduced power, in the caso I hare quoted, was produced bj increasing the rute of cxpansion; that was so. $\Lambda_{3}$ the power ras redued so the cut-off was made to take place carlier and the jucket pressure at the same time suitably adjustcd. Undoubtedly this increased rute of expansion was an important factor in obtaining the cconomy at tho lower power. I hure not the figures at present as to the temperature of feed kater in the casc of tho "Thunderer," when she craporated 9.6 lbs. of water for each lb. of fucl ; the tem. perature of the feed water is, howerer, that at which it was supplicd to the boilers on hourd. I think I may say roughly it did not exceed $100^{\circ}$, and tho boiles pressurc nas 110 lbs.'

The Chalesax ( $\Delta$ dmiral Clureh): It is my duty now to bring this discussion to a close. I perfectly agrce with Mir. White as to the great ralue of this paper, particularly to the executive officers of the flect, more especially the oficers in com. mand of Her Irajesty's ships. My opinion most entirely coincides with what has fallen from Prince Louis of Battenberg about the economy nade in the auriliary cagines. There is no doubt that these engines are put into tlie ships to male them more cilfient for the war purposcs for which they are built, and if too much cconomy is obscried in peace-time we should not be well up to working those rery cagincs which re should hate to use in war-time. I think it is absolutely neceseary to use these engines in peace-time as we shall hase to do in wur. There is no doubt that in war-tine the electric lighting of cabine and of the mess rooms will be dispensed with, but I do not ece, mreclf, what other cconomy in that respect no could carrs out. I think me are rers much indebted to MIr. Riles for this admirable paper so clererly drawn up, and also particularly for the diagrams which he has giren us and which will be nost useful in future. I am sure I am fulfilling the wishes of all present when I thank MIr. Rileg rerg much for his paper.

2 Since reading this paper I bare been macle aware that the method described in it of oblaining the wost cconomical speed is not uew.-W. II. IR. 